\title{
DIAGNOSTICS AND MAKING DECISION IN CONFLICT MANAGEMENT AT THE ENTERPRISE
}

\author{
Semenchenko Alina ${ }^{1}$, Nazarova Galina ${ }^{2}$, Semenchenko Andrii ${ }^{3}$, Nazarov Nikita ${ }^{4}$,Urdukhanov \\ Rustam $^{5}$
}

${ }^{1}$ PhD in Economics. Assistant Professor, Department of Social Economics, Simon Kuznets Kharkiv National University of Economics. Kharkiv, Ukraine, Ave.Science, 9-A, 61166.Email: alya_semenchenko@ukr.net

${ }^{2}$ Full Professor, Doctor of Sciences (Economics), Head of Social Economics Department. Simon Kuznets Kharkiv National University of Economics. Kharkiv, Ukraine. Ave. Science, 9-A, 61166. Email: gnazarova.ua@gmail.com

${ }^{3}$ PhD in Economics, Assistant Professor, Department of Social Economics. Simon Kuznets Kharkiv National University of Economics. Kharkiv, Ukraine. Ave. Science, 9-A, 61166. Email: andrii.semenchenko@hneu.net

${ }^{4}$ PhD in Economics, Assistant Professor, Department of Management and Business, Simon Kuznets Kharkiv National University of Economics. Kharkiv, Ukraine. Ave. Science, 9-A, 61166. Email:nikita_nazarov@yahoo.com

${ }^{5}$ Department of Social Economics, Simon Kuznets Kharkiv National University of Economics. Kharkiv, Ukraine. Ave. Science, 9-A, 61166. E-mail: urdukhanov.rustam@gmail.com

Received 0503 2021; Accepted 12052021

\begin{abstract}
The period of overcoming crises in society due to pandemics, declining economic growth, social stratification, job loss in business is characterized by political and social instability, which creates conflict situations at all levels of the social hierarchy. The transformation of modern political and economic institutions, the development of processes of reforming society are accompanied by a deepening of the contradictions between the interests and needs of different social groups and individuals. The purpose of the article is to review the main sources and causes of conflicts, and also ways to solve them in the enterprise. The main methods of resolving resource conflicts are: negotiations, information and clarification of conflicts. Conflicts of goals, values and communications are also resolved using the most effective methods inherent in these types of conflicts.
\end{abstract}

Keywords: conflict, diagnostics, enterprise, management, transformation.

JEL Codes: O1, O2, O3.

\section{Introduction}

Statement of the main problem. The practice of entrepreneurship confirms that in terms of organizational development structures a special place in any team is occupied by conflict. This is because conflict is an integral part of every business. Therefore, there is a need for in-depth study modern patterns of formation of organizational conflicts, ways to eliminate them and combating their consequences. The most important result of effective conflict management in the enterprise will be the formation of a mechanism for early warning conflict situations and liquidation mechanism conflicts that have already arisen.

The analysis of existing scientific sources on the researched problem testifies to the presence of significant contributions to the solution of the problem of conflict management. First of all, it is necessary to highlight the works of such domestic authors as: A. Antsupov, N. Grishin, S. Erina, A. Kovalev, N. Leonov. Among foreign authors a significant contribution was made

Copyright (C) 2021 Author(s), published by Vytautas Magnus University. This is an open access article distributed under the terms of the Creative Commons Attribution Non-Commercial 4.0 (CC BY-NC 4.0) license, which permits unrestricted use, distribution, and reproduction in any medium provided the original author and source are credited. The material cannot be used for commercial purposes. 
by K. Boulding, I. Galtwing, R. Darendorf, M. Deutsch, L. Kozer, D. March, J. Robinet, M. Spencer. In these scientific publications, the authors define the structure, functions and process of labor conflicts, reveal the specifics of conflict consciousness, provide methods of conflict management, but do not reflect the features of conflict management in the personnel management system of the enterprise. Thus, in 2020, the NSPP contributed to the resolution of 377 collective labor disputes (conflicts) (3-at the national, 3 - at the sectoral, 6 - at the territorial, 365 - at the production level), which directly involved more than 1.4 million employees 6778 sub of economic entities.

\section{Results}

During the last year, the NSPP and its branches in the regions organized the relevant work on the timely and objective consideration of 1596 appeals of citizens, letters of legal entities and representatives of associations of citizens without legal personality, which raised 1728 issues (Fig. 1).

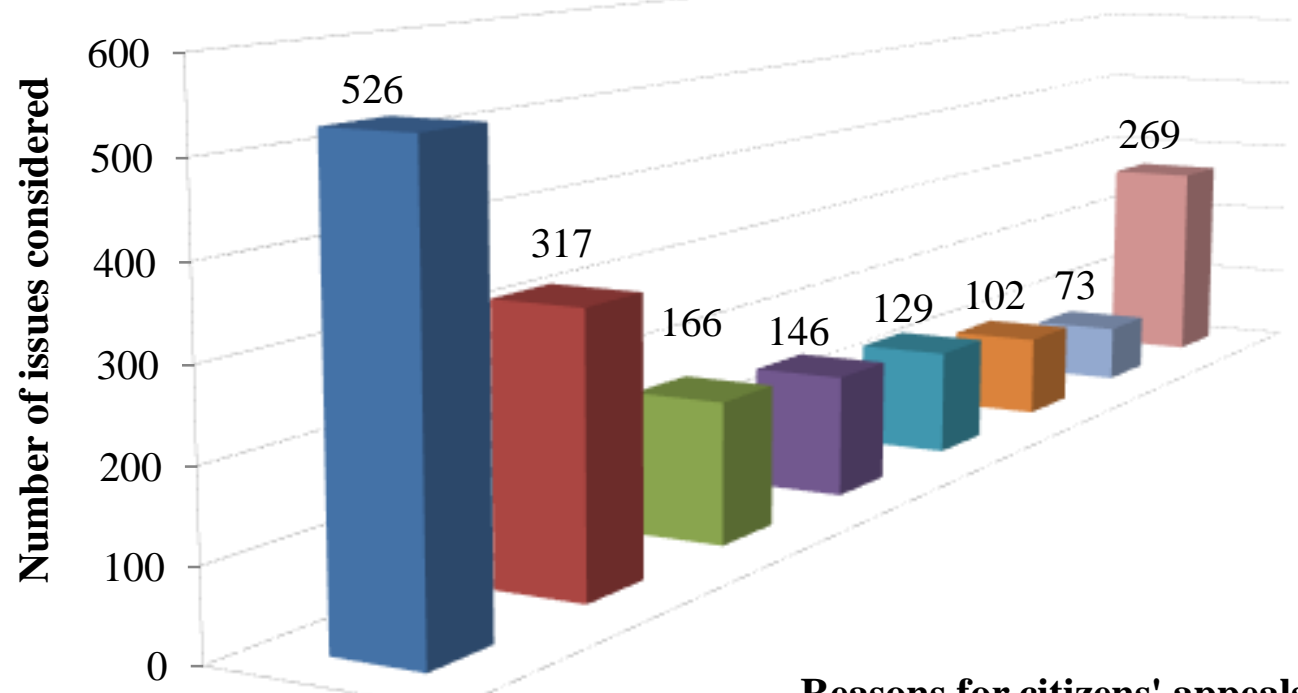

Reasons for citizens' appeals

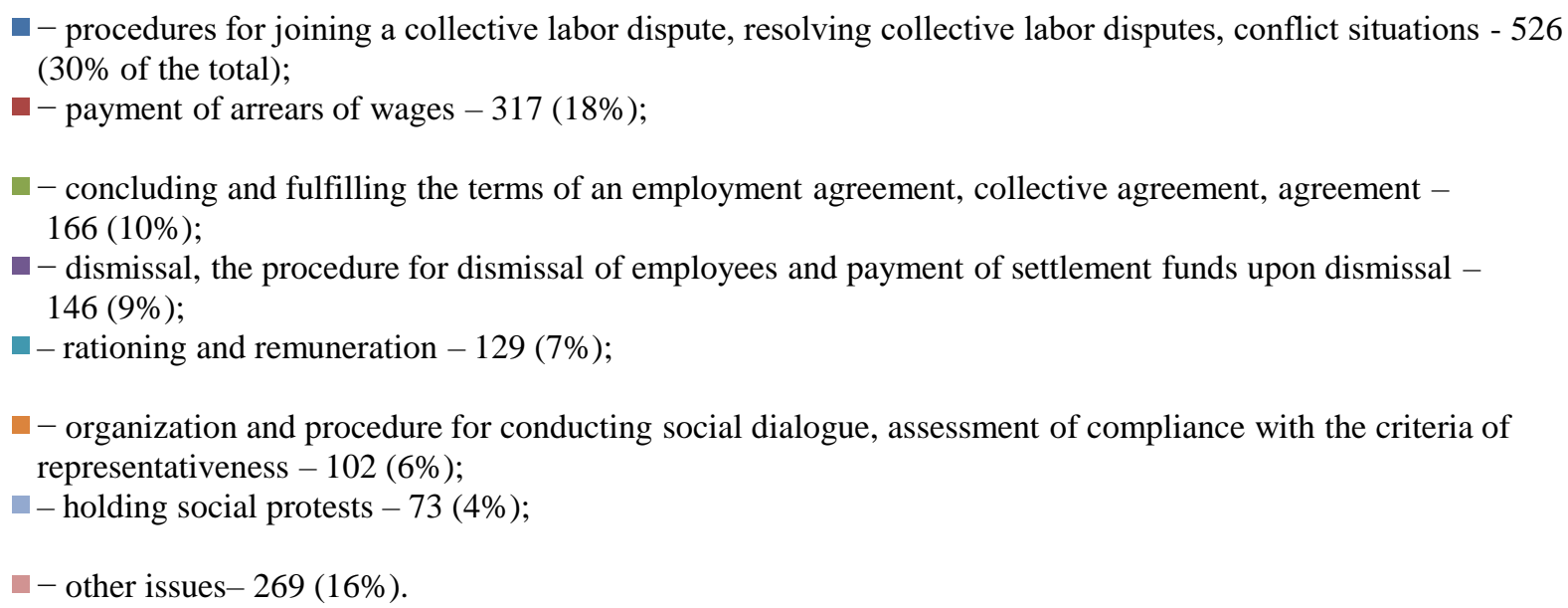

Figure 1. The number of considered NSPP appeals of citizens and analysis of the reason for these appeals, in numbers

In particular, regarding: procedures for joining a collective labor dispute, resolving collective labor disputes, conflict situations -
526 (30\% of the total); payment of arrears of wages - $317(18 \%)$; concluding and fulfilling the terms of an employment agreement, 
collective agreement, agreement - $166(10 \%)$; organization and procedure for conducting social dialogue, assessment of compliance with the criteria of representativeness -102 (6\%); holding social protest actions - $73(4 \%)$; other issues - 269 (16\%).

Representatives of the early schools of management believed that the conflict was a sign of inefficient organization and poor management. Conflicts are recognized by modern sociologists as the most important factors of social development.

The English scientist M. Spencer considered the conflict "an inevitable phenomenon in the history of human society and a stimulus for social development". German sociologist

R. Darendorf put political factors at the heart of social conflicts: the struggle for power, prestige, and authority [14, p. 93].

Traditionally a split of the conflict includes three stages: pre-conflict, conflict and post-conflict situations. In turn, each stage is divided into phases [15, p. 226].

An attempt to systematize the existing approaches to the classification of labor conflicts makes it possible to propose a generalized classification of conflicts, which is presented in Fig. 2.

There are 3 main groups of conflicts: depending on their prevalence, depending on the causes and depending on the level of occurrence and resolution of conflicts.

A conflict of resources - their cause is the objective limitation of any resources at all levels, including at the state level. Conflicts of purposes - is the most typical kind of positional conflicts originating from different divisions goals and organizations in the solution of common problems.

Conflicts of values arise from differences in the subjective views of opponents of a set of values, which may relate to worldview, morality, religious views and more. Conflicts of communication - arise from lack of information in the process of work.

And also, to be distinguished: industrial, sectoral, territorial and national conflicts [5, p. 246].

The positive functions include:

integration function, which is to strengthen the cohesion of groups during the conflict, uniting them on the basis of awareness of common interests and goals;

transformation function that is implemented through conflict resolution by improving social and psychological climate of collective and intensification of social activity of employees;

stabilization function, which is to resolve a minor conflict, which prevents a more serious conflict.

Copyright (C 2021 Author(s), published by Vytautas Magnus University. This is an open access article distributed under the terms of the Creative Commons Attribution Non-Commercial 4.0 (CC BY-NC 4.0) license, which permits unrestricted use, distribution, and reproduction in any medium provided the original author and source are credited. The material cannot be used for commercial purposes. 


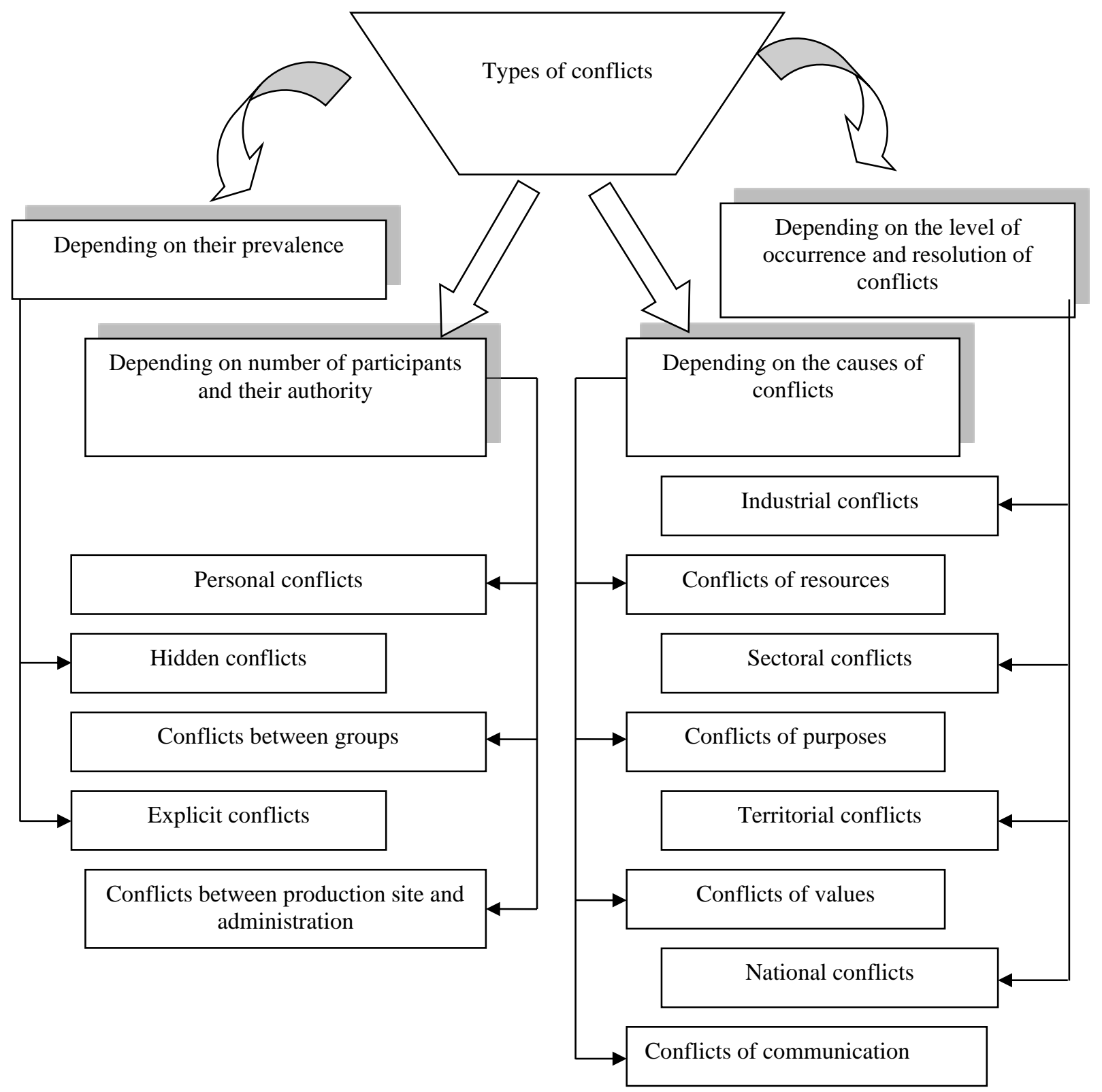

Figure 2. Generalized classification of conflicts

(Developed by the authors)

The negative functions of labor conflict include:

strengthening hostility, increased negative expressions and mutual evaluations, deterioration of social well-being and selfidentification of people in the labor environment;

curtailment of business contacts despite functional necessity, extreme formalization of communication, rejection of public utilities;

intentional and purposeful destructive behavior, the attitude to the destruction and undermining of certain common ties, organization, culture and traditions; the actual loss of time, a distraction from work or non-favorable situation, opportunities and chances to achieve something through struggle.

Causes of collective labor disputes (conflicts) - circumstances, facts, trends of objective or subjective nature, or their combination in economic, social, industrial, legal areas, the action of which has led to negative consequences for employees and the emergence of collective labor dispute [10, p. 445].

The basis of the analysis of the causes of labor conflict is the methodological principle 
of causality. According to this principle, there is a causal link between two events if the first event is a sufficient condition for the next event to take place.

The causes are the basis of the conflict and include: structural differentiation (D. March and G. Simon, J. Robin); lack of resources (S. Kerr, K. Boulding); deep geological differences (R. Converse) and dominance (I. Haltunh) [2, p. 177].

The resolution is not seen as some independent process over the labor conflict. This is the final stage of the conflict process. It is achieved either through changing objective situation or psychological adjustment of subjective image of the situation that has emerged in the warring parties. Forms of resolving labor conflicts are presented in Fig. 3 [17, p. 324].

Undoubtedly, the judgments and visions of probable solutions to the problem of individual employees of the enterprise, analyzed in generalized form, will be able to provide an idea of the most meaningful vision of employees to resolve the problem of conflict management in personnel management.

Therefore, in order to improve the current situation regarding the emergence of conflict situations at one of the industrial enterprises of Kharkiv, a study was conducted in one of the methods of collecting information - the method of questionnaires. The content of the questionnaire and the results of the survey are given in table 1 . In the process of questionnaires, the most important tasks were to identify the causes of conflicts at all levels of social structure, forms and possible ways to resolve labor conflicts. Among the respondents, $75 \%$ were men, $25 \%$ women; average age 43 years, ranging from 32 to 58 years; by marital status: $80 \%$ - married, $15 \%$ - single, $5 \%$ are divorced; by nationality, all respondents are Ukrainian. All have higher education, one of the respondents has a degree; $70 \%$ of respondents rated their standard of living as average, 25\% - high, 5\% - low; work experience at the enterprise ranges from 4 to 33 years [16].

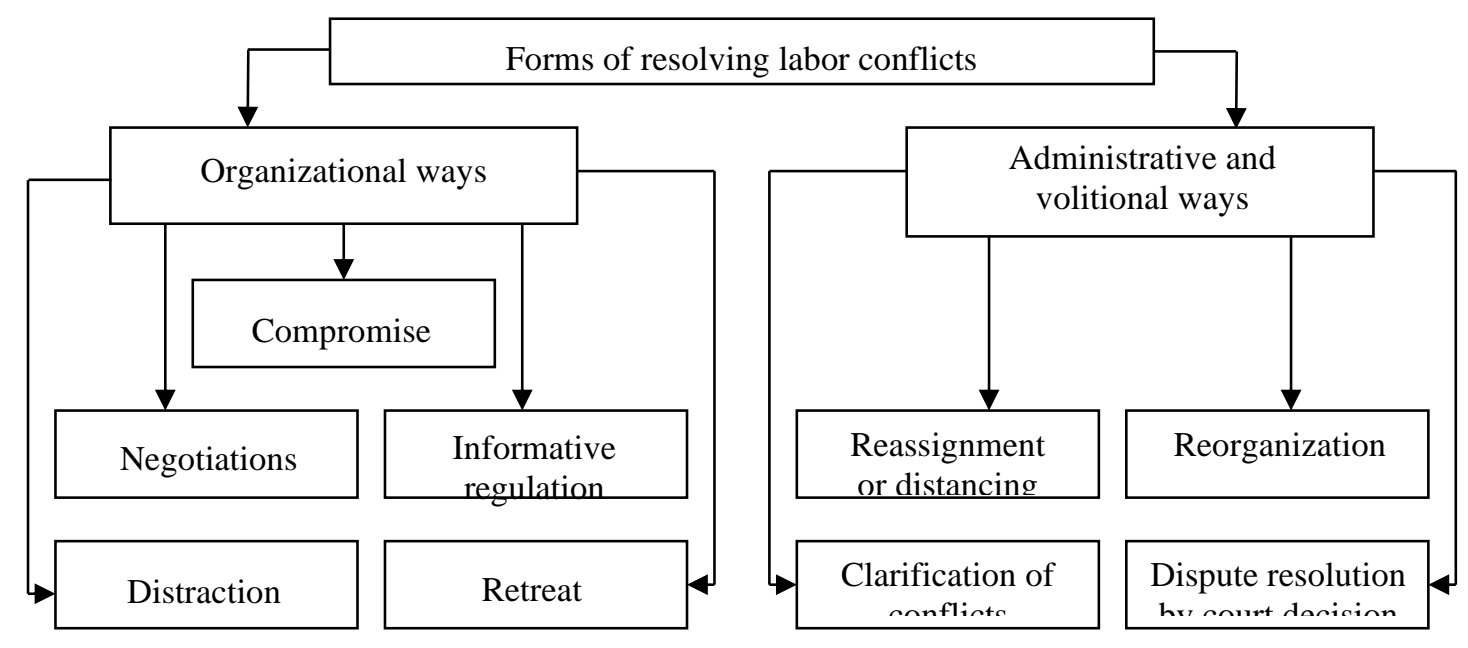

Figure 3. Forms of resolving labor conflicts

(Developed by the authors)

According to the results of the survey, the ratio between hidden and explicit conflicts averages $94.5 \%$ to $5.5 \%$ respectively.
According to respondents, they believe that the most effective forms of conflict resolution are: organizational ways of overcoming conflicts - $75 \%$ of answers,

Copyright (C 2021 Author(s), published by Vytautas Magnus University. This is an open access article distributed under the terms of the Creative Commons Attribution Non-Commercial 4.0 (CC BY-NC 4.0) license, which permits unrestricted use, distribution, and reproduction in any medium provided the original author and source are credited. The material cannot be used for commercial purposes. 
administrative and volitional ways of resolving conflicts $-25 \%$ of respondents. According to the results of respondents' answers to the questionnaire, in which employees were given the opportunity to determine, in their opinion, which methods of conflict resolution are best used in resolving specific types of conflicts, it became possible to build a summary table of possible forms of conflict resolution is reflected in table. 2.

Table 1. The results of the survey of employees of industrial enterprises

\begin{tabular}{|c|c|c|c|}
\hline № & Contents of the question & $\begin{array}{c}\text { Total number } \\
\text { of answers }\end{array}$ & $\%$ \\
\hline 1. & $\begin{array}{l}\text { Have you ever been involved in resolving a conflict? } \\
1 \text { yes (interpersonal conflict) } \\
2 \text { yes (intergroup production conflict) } \\
3 \text { yes (conflict between production groups and administration) } \\
\end{array}$ & $\begin{array}{l}1-20 \\
2-8 \\
3-9\end{array}$ & $\begin{array}{l}1-100 \% \\
2-40 \% \\
3-45 \%\end{array}$ \\
\hline 2. & $\begin{array}{l}\text { Have you ever been a representative of one of the parties to a collective labor } \\
\text { dispute (conflict)? } \\
1 \text { yes (once) } \\
2 \text { yes (repeatedly) } \\
3 \text { no }\end{array}$ & $\begin{array}{l}1-10 \\
2-7 \\
3-3\end{array}$ & $\begin{array}{l}1-50 \% \\
2-35 \% \\
3-15 \%\end{array}$ \\
\hline 3. & $\begin{array}{l}\text { Have you ever been in the resolution of a collective labor dispute: } 1 \text { member } \\
\text { of the conciliation commission? } \\
2 \text { independent intermediaries } \\
3 \text { members of the labor arbitration } \\
4 \text { a representative of the National Mediation and Con.Service }\end{array}$ & $\begin{array}{l}1-5 \\
2-2 \\
4-1\end{array}$ & $\begin{array}{l}1-25 \% \\
2-10 \% \\
4-5 \%\end{array}$ \\
\hline 4. & $\begin{array}{l}\text { What is the percentage of closed and open conflicts that occur in the } \\
\text { enterprise? } \\
\begin{array}{ll}195 \% \text { to } 5 \% & 290 \% \text { to } 10 \% \\
385 \% \text { to } 15 \% & 480 \% \text { to } 20 \%\end{array}\end{array}$ & $\begin{array}{c}1-18 \\
2-2\end{array}$ & $\begin{array}{l}94.5 \%- \\
5.5 \%\end{array}$ \\
\hline 5. & $\begin{array}{l}\text { Rank the following types of conflicts according to the frequency of their } \\
\text { occurrence in your company in } 2019-2020 \text { : } \\
1 \text { resource conflicts } \\
3 \text { conflicts of values }\end{array}$ & $\begin{array}{l}1: 2,18,0,0 \\
2: 18,2,0,0 \\
3: 0,0,15,5 \\
4: 0,0,5,15\end{array}$ & $\begin{array}{l}1-31 \% \\
2-39 \% \\
3-17.5 \% \\
4-12.5 \%\end{array}$ \\
\hline 6. & $\begin{array}{l}\text { What do you think are the most effective forms of conflict resolution? } \\
1 \text { organizational ways of overcoming conflicts } \\
2 \text { administrative and volitional ways of resolving conflicts }\end{array}$ & $\begin{array}{l}1-15 \\
2-5\end{array}$ & $\begin{array}{l}1-75 \% \\
2-25 \%\end{array}$ \\
\hline 7. & $\begin{array}{l}\text { What do you think are the most effective ways to resolve conflicts when } \\
\text { resolving closed conflicts? } \\
1 \text { compromise } 6 \text { suppression of personal interests } \\
2 \text { negotiations } 7 \text { transfer to another job } \\
3 \text { distractions } 8 \text { clarification of conflicts } \\
4 \text { informing } 9 \text { the resolution of the dispute by court decision }\end{array}$ & $\begin{array}{l}1-2 \\
3-12 \\
4-15 \\
5-1 \\
7-4 \\
8-17\end{array}$ & $\begin{array}{l}1-10 \% \\
3-60 \% \\
4-75 \% \\
5-5 \% \\
7-20 \% \\
8-85 \%\end{array}$ \\
\hline 8. & 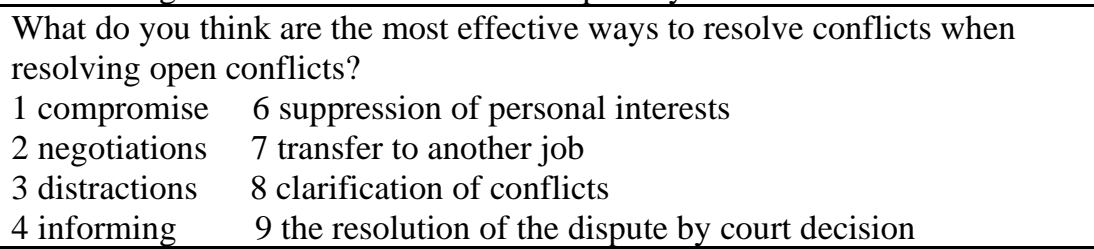 & $\begin{array}{l}1-13 \\
2-15 \\
4-2 \\
5-12 \\
8-4 \\
9-18\end{array}$ & $\begin{array}{c}1-65 \%, 2- \\
75 \%, 4- \\
10 \%, 5- \\
60 \%, 8- \\
20 \%, \\
9-90 \%\end{array}$ \\
\hline 9. & $\begin{array}{l}\text { What do you think are the most effective ways to resolve conflicts when } \\
\text { resolving resource conflicts? } \\
1 \text { compromise } 6 \text { suppression of personal interests } \\
2 \text { negotiations } 7 \text { transfer to another job } \\
3 \text { distractions } \quad 8 \text { clarification of conflicts }\end{array}$ & $\begin{array}{l}1-5,2-15,3-1 \\
4-17,5-4,6-2 \\
8-18\end{array}$ & $\begin{array}{l}1-25 \% \\
2-65 \% \\
3-5 \% \\
5-20 \% \\
6-10 \%\end{array}$ \\
\hline 10. & $\begin{array}{l}\text { What conflict resolution do you think is most effective in using when } \\
\text { resolving goal conflicts? } \\
1 \text { compromise } 6 \text { suppression of personal interests } \\
2 \text { negotiations } \quad 7 \text { transfer to another job } \\
3 \text { distractions } \quad 8 \text { clarification of conflicts }\end{array}$ & $\begin{array}{l}1-3,2-17,3-2 \\
5-4,6-15 \\
7-16,8-2,9-5\end{array}$ & $\begin{array}{l}1-15 \% \\
2-85 \% \\
3-10 \% \\
8-10 \% \\
9-25 \%\end{array}$ \\
\hline 11. & $\begin{array}{l}\text { What do you think are the most effective ways to resolve conflicts when } \\
\text { resolving conflicts of values? }\end{array}$ & $\begin{array}{l}1-14 \\
2-6\end{array}$ & $\begin{array}{l}1-70 \% \\
2-30 \%\end{array}$ \\
\hline
\end{tabular}




\section{sciendo}

Management Theory and Studies for Rural Business and Infrastructure Development eISSN 2345-0355. 2021. Vol. 43. No. 2: 259 - 268

Article DOI: https://doi.org/10.15544/mts.2021.22

\begin{tabular}{|l|l|l|l|}
\hline & 1 compromise 6 suppression of personal interests & $3-12$, & $3-60 \%$, \\
& 2 negotiations 7 transfer to another job & $7-3$, & $7-15 \%$, \\
& 3 distractions 8 clarification of conflicts & $8-17$ & $8-85 \%$ \\
\hline \multirow{4}{*}{12.} & What do you think are the most effective ways to resolve conflicts when & $1-4$, & $1-20 \%$, \\
& resolving communication conflicts? & $4-17$, & $2-90 \%$, \\
& 1 compromise 6 suppression of personal interests & $5-2$, & $5-10 \%$, \\
& 2 negotiations 7 transfer to another job & $6-1$, & $6-5 \%$, \\
& 3 distractions 8 clarification of conflicts & $8-14$ & $8-70 \%$ \\
\hline
\end{tabular}

Thus, it is possible to solve the problem of conflict resolution, based on the results of the survey of employees of the enterprise presented in table 1 and the data of the summary table of possible forms of conflict resolution taking into account the answers of the respondents presented in table 2 .

Table 2. Possible ways of resolving conflicts taking into account the answers of the respondents

\begin{tabular}{|c|c|c|}
\hline Types of conflicts & Ways to resolve conflicts & $\begin{array}{c}\text { Weight of } \\
\text { respondents' } \\
\text { answers, \% }\end{array}$ \\
\hline \multirow{5}{*}{ Hidden conflicts } & clarification of conflicts & 85 \\
\hline & informing & 75 \\
\hline & distraction & 60 \\
\hline & transfer to another job & 20 \\
\hline & retreat & 5 \\
\hline \multirow{3}{*}{ Explicit conflicts } & dispute resolution by court decision & 90 \\
\hline & negotiations & 75 \\
\hline & compromise & 65 \\
\hline \multirow{4}{*}{ Resource conflicts } & clarification of conflicts & 90 \\
\hline & negotiations & 65 \\
\hline & compromise & 25 \\
\hline & retreat & 20 \\
\hline \multirow{6}{*}{ Conflicts of purpose } & negotiations & 85 \\
\hline & transfer to another job & 80 \\
\hline & suppression of personal interests & 75 \\
\hline & dispute resolution by court decision & 25 \\
\hline & retreat & 20 \\
\hline & distraction & 10 \\
\hline \multirow{6}{*}{ Conflicts of values } & clarification of conflicts & 85 \\
\hline & compromise & 70 \\
\hline & distraction & 60 \\
\hline & negotiations & 30 \\
\hline & transfer to another job & 15 \\
\hline & retreat & 10 \\
\hline \multirow{6}{*}{ Conflicts of communication } & negotiations & 90 \\
\hline & informing & 85 \\
\hline & clarification of conflicts & 70 \\
\hline & distraction & 20 \\
\hline & retreat & 10 \\
\hline & suppression of personal interests & 5 \\
\hline
\end{tabular}

Copyright (C) 2021 Author(s), published by Vytautas Magnus University. This is an open access article distributed under the terms of the Creative Commons Attribution Non-Commercial 4.0 (CC BY-NC 4.0) license, which permits unrestricted use, distribution, and reproduction in any medium provided the original author and source are credited. The material cannot be used for commercial purposes. 
It will be the creation of combinations of types of conflicts presented in fig. 1, with the most effective ways of resolving them (the most effective are those ways of resolving conflicts there the weight of the answers of the respondents is more than 50\%), which is reflected in fig. 3 .

As can be seen from fig. 4 hidden conflicts can be resolved through methods such as distraction, information and conflict resolution; explicit conflicts are resolved by compromise, negotiation, withdrawal or by court order. It will be the creation of combinations of types of conflicts presented in fig. 1 , with the most effective ways of resolving them (the most effective are those ways of resolving conflicts there the weight of the answers of the respondents is more than $50 \%$ ), which is reflected in fig. 3. As can be seen from fig. 4 hidden conflicts can be resolved through methods such as distraction, information and conflict resolution; explicit conflicts are resolved by compromise, negotiation, withdrawal or by court order.

The main methods of resolving resource conflicts are: negotiations, information and clarification of conflicts. Conflicts of goals, values and communications are also resolved using the most effective methods inherent in these types of conflicts.

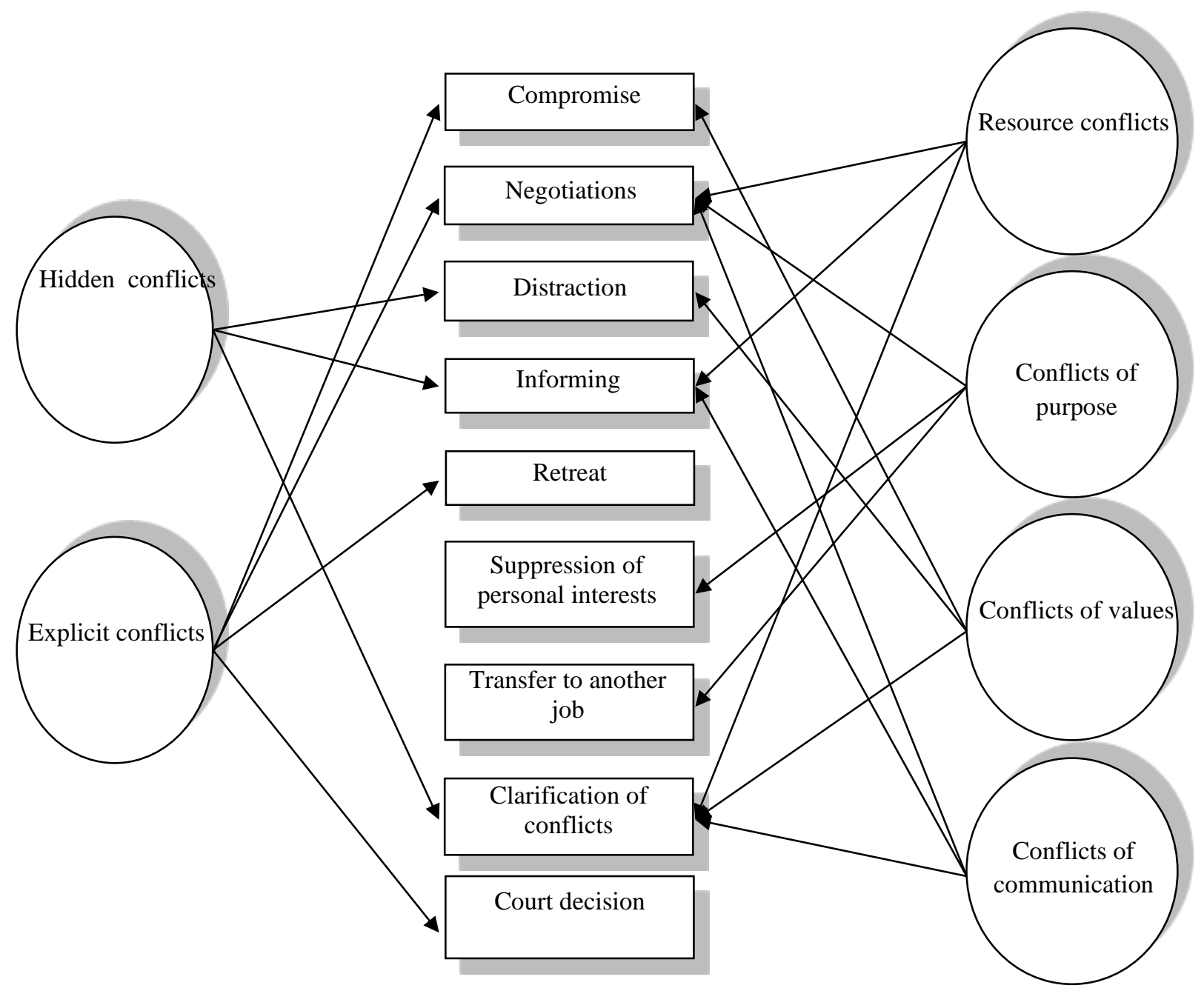

Figure 4. Possible ways of resolving conflicts taking into account the answers of the respondents (Developed by the authors) 


\section{Conclusion}

For the most effective management of a conflict situation, it is necessary to plan and forecast reaction to it, then application of the created combinations presented in fig. 3 enables employees of the enterprise, who directly interact with personnel, to have readymade models of behavior in a particular management situation, to resist a particular type of conflict using the most effective methods inherent in this type.

The application of this system will allow for the fastest response and resolution of conflict situations, prevention of unnecessary material, financial, time and emotional costs.

Due to timely resolution (and even better - prevention) of conflict situations, any company can easily achieve the planned financial and economic goals due to the united and fruitful work of the team.

\section{References}

Antsupov A.Y., Baklanovsky S.V. (2005). Conflictology in schemes and comments. - SPb. : Petersburg. 288 p.

Bilovodska, O. A Upravlinnia konfliktami $\mathrm{v}$ sistemy upravlinnia lyudskym potentsialom pidpryiemstv [Management of conflicts in the management system of human potential of enterprises] [Electronic resource]. - No. 10: 177-182. - http://www.economyandsociety.in.ua/journal/10_ukr/33.pdf. [2017 06 02].

Boushey Heather Finding Time: The Economics of Work-Life Conflict Paperback (2019). - Harvard University Press. 360 p.

Belovodskaya, O. A. (2017). Conflict management in the human resource management system of enterprises // Economy and Society. No. 10: 177-182.

Furlong Gary T. The Conflict Resolution Toolbox: Models and Maps for Analyzing, Diagnosing, and Resolving Conflict.2-nd Edition. (2020) - The John Wiley \& Sons Inc. 246 p.

Goncharova S. Y., Otenko I. P. Social policy. Tutorial. (2003). - Kharkiv: Ed. KhDEU. 200 p.

Grishina N.bV. Psychology of conflict. (2000). SPb. : Petersburg. 256 p.

Information on the results of the National Mediation and Reconciliation Service for 2020. https://www.nspp.gov.ua/home/struktura-nspp-5/13950-informatsiia-pro-rezultaty-diialnosti-natsionalnoi-sluzhbyposerednytstva-i-prymyrennia-za-2020-rik [2020 12 08].

Kolot, A. (2002). Problems of building a national model of social and labor relations // Ukraine: aspects of labor. No. 5: 23-28.

Kurbatov V.I., Conflictology (2005). Rostov: Phoenix. 445 p.

Labor economics and social and labor relations. (2004). Textbook / S.M. Pilipenko, A.A. Pilipenko, I.O. Shade .Kharkiv: Ed. KhNEU. 224 p.

Mastenbrut W. Management of conflict situations and Development organization. (1996). - M. 247 p.

Morgunov E. N., Ryazanova N. A. (2005). Business Conflictology/ Personnel Management. No. 16. 82 p.

Mayer Bernard S. (2012). The Dynamics of Conflict: A Guide to Engagement and Intervention 2nd Edition. Jossey-Bass A Wiley Imprint. 386 p.

Nazarova G., Jaworska M., Nazarov N., Dybach I. \& Demianenko A. (2019). Improvement of the method measuring the security of human development: case of Ukraine. Problems and Perspectives in Management. No. 17(4): 226-238. DOI: http://dx.doi.org/10.21511/ppm.17(4). 2019.19.

Nazarova G., Demianenko A. (2018). Analysis of the human security in Ukraine in a regional perspective. Social and labour relations: theory and practice. No. 8(2): 1-7.

Nazarova G.V. (2010). Upravlinnia sotsialno-trudovyu spheroi pidpryiemstva [Management of the social and labor sphere of the enterprise]. Nazarova, G.V. Vodnitskaya N. V.; for general ed. Doctor of Economics, Professor G.V. Nazarova - Kharkiv: Ed. KhNEU. 324 p.

Nazarov, N. K. (2014). Conflicts in the enterprise: definition, causes, types [Electronic resource] / N. K. Nazarov // Scientific Bulletin of Kherson State University. Series: Economic Sciences. Vip. 5 (2): 198-201. http://nbuv.gov.ua/UJRN/Nvkhdu_en_2014_5\%282\%2954.

Copyright (C) 2021 Author(s), published by Vytautas Magnus University. This is an open access article distributed under the terms of the Creative Commons Attribution Non-Commercial 4.0 (CC BY-NC 4.0) license, which permits unrestricted use, distribution, and reproduction in any medium provided the original author and source are credited. The material cannot be used for commercial purposes. 
Semenchenko Alina, Nazarova Galina, Semenchenko Andrii, Nazarov Nikita, Urdukhanov Rustam Diagnostics and Making Decision in Conflict Management at the Enterprise

Polishchuk, L. M. Features of labor behavior of employees in conflict. http://elar.khnu.km.ua/jspui/bitstream/123456789/6401/1/\%D0\%A5\%D0\%B8\%D1\%82\%D1\%80\%D0\%B0_\%D0\%9E $\%$ D0\% 92_\% D0\% A1\% D1\% 82\% D0\% B.doc. [2017 05 02].

Social economy (2018). / G.V. Nazarova, S. Yu. Goncharova, Yu. V. Sotnikova, N. V. Agramakova - Kharkiv: KhNEU. S. Kuznets. 284 p. 